\title{
Growing Cassava (Manihot esculenta) in Mato Grosso, Brazil: Genetic Diversity Conservation in Small-Scale Agriculture ${ }^{1}$
}

\author{
N. F. Carrasco ${ }^{1}$, J. R. L. Olere ${ }^{2}$, F. F. Marchetti $^{2}$, M. A. Carniello ${ }^{3}$, \\ M. C. M. Amorozo ${ }^{2}$, T. L. Valle ${ }^{4}$, and E. A. Veaser ${ }^{*}, 1$
}

${ }^{1}$ Departamento de Genética, Escola Superior de Agricultura “Luiz de Queiroz”, Universidade de São Paulo (ESALQ/USP), Piracicaba, São Paulo, Brazil

${ }^{2}$ Departamento de Ecologia, Universidade Estadual Paulista Júlio de Mesquita Filho, Rio Claro, SP, Brazil

${ }^{3}$ Departamento de Ciências Biológicas, Campus de Cáceres, MT, Faculdade de Ciências Agrárias e

Biológicas, Universidade Estadual de Mato Grosso (UNEMAT), Cáceres, MT, Brazil

${ }^{4}$ Instituto Agronômico de Campinas, Seção de Horticultura, Campinas, SP, Brazil

*Corresponding author; e-mail: eaveasey@usp.br

\begin{abstract}
Growing Cassava (Manihot esculenta) in Mato Grosso, Brazil: Genetic Diversity Conservation in Small-Scale Agriculture. Cassava (Manihot esculenta Crantz) is a tropical species that stands out as a food source for developing countries. Within an ethnobotanical and socioeconomic context, this study aimed to compare the level of genetic diversity of cassava maintained by small farmers in three municipalities of the Cuiabá Lowland in the state of Mato Grosso, Brazil: Cáceres, Porto Estrela, and Santo Antônio do Leverger. This region, which is included in the center of origin of cassava, is currently undergoing profound socioeconomic changes that can have negative impacts in the on farm conservation of cassava agrobiodiversity. We characterized 211 genotypes collected in 40 households in 10 communities, using 14 microsatellite loci. High levels for the observed $\left(H_{O}=0.587\right)$ and expected $\left(H_{E}=0.525\right)$ heterozygosities were found, whereas most of the genetic diversity was concentrated within communities (92\%). A genetic differentiation was found between the municipality of Santo Antônio do Leverger and the municipalities of Cáceres and Porto Estrela, not only due to a higher geographic distance among them, but also due to soil, climatic, and cultural factors. A different number of local varieties was observed in each municipality, while the number of unique varieties in each municipality was high, $83 \%, 84 \%$, and $61 \%$, respectively, representing an important aspect for the in situ conservation of this crop. Although local names provided by farmers were phenotypically coherent, intravarietal variability among local varieties sharing the same name was high (97\%). Santo Antônio do Leverger was considered as a priority area for in situ conservation. Nevertheless, in view of the decline in local traditional agriculture systems and socioeconomic transformations in this region, public policies providing support and incentives to farmers are necessary.
\end{abstract}

Cultivo de mandioca (Manihot esculenta) em Mato Grosso, Brasil: conservaçáo da diversidade genética em agricultura de pequena escala. A mandioca (Manihot esculenta Crantz) é uma espécie tropical que se destaca como uma fonte de alimento para os países em desenvolvimento. Dentro de um contexto etnobotânico e sócio-econômico, este estudo teve como objetivos comparar o nível de diversidade genética da mandioca mantida por pequenos agricultores em três municípios, Cáceres, Porto Estrela e Santo Antônio do Leverger, na Baixada Cuiabana, Estado de Mato Grosso. Esta área está incluída no centro de origem da mandioca e vem atualmente sofrendo profundas mudanças sócio-econômicas que podem ter impactos negativos na conservação on farm da agrobiodiversidade. Nós caracterizamos 211 genótipos coletados em 40 roças em 10 comunidades, utilizando 14 locos microssatélites. Elevados níveis para a heterozigosidade observada $\left(H_{O}=0,587\right)$ e esperada $\left(H_{E}=0,525\right)$ foram observados, sendo que a maior parte da diversidade genética está concentrada dentro de comunidades (92\%). Foi encontrada uma diferenciação genética entre o município de Santo Antônio do Leverger e os municípios de Cáceres e Porto Estrela, não apenas devido à maior distância geográfica entre eles, mas também em funçáo de solo, clima e fatores culturais. Observou-se um número diferente de variedades locais em cada município, sendo que o número de variedades exclusivas

\footnotetext{
${ }^{1}$ Received 25 June 2015; accepted 13 January 2016; published online 18 February 2016
} 
em cada município foi elevado, 83\%, 84\% e 61\%, respectivamente, o que representa um aspecto importante da conservação in situ desta cultura. Apesar dos nomes populares fornecidos pelos agricultores serem fenotipicamente coerentes, a variabilidade intravarietal entre as variedades locais que compartilham o mesmo nome foi alta (97\%). Santo Antônio do Leverger foi considerada como uma área prioritária para a conservação in situ. No entanto, em vista do declínio dos sistemas agrícolas tradicionais e das transformaçóes socioeconômicas na região, políticas públicas que deem suporte e incentivo aos agricultores são necessárias.

Key Words: Genetic structure, local varieties, Manihot esculenta, microsatellites, traditional agriculture, ethnobotany.

\section{Introduction}

Cassava (Manihot esculenta Crantz) is grown throughout the tropics, representing the sixth largest crop produced in the world (252 million tons) (FAOSTAT 2013). This crop, which has played an important role in world agriculture, is mostly cultivated for the starch contained in the storage roots, reaching about $80 \%$ of starch in the dry matter (Sriroth et al. 2000). It is often grown in gardens of indigenous agriculture, presenting good growth in poor soils, being resistant to pests and diseases, and adapting to different edapho-climatic conditions (El-Sharkawy 2004). The high genetic variability of existing local varieties in households of traditional farmers (Peña-Venegas et al. 2014; Peroni et al. 2007; Siqueira et al. 2010; Yong-Bi et al. 2014) is a valuable resource for in situ conservation. In the tropics, farmers combine species and varieties with differing habits and ecological preferences in their fields and yards in such a way that complex agro-ecosystems are established, occupying various strata, above as well as below ground. These diverse systems allow the entry and assimilation of new species originating from local/regional exchanges (Amorozo 2008).

Microsatellites or simple sequence repeats (SSRs) have been employed in the characterization of genetic diversity among accessions of germplasm banks and local varieties of cassava (Chepkoech et al. 2015; Mezette et al. 2013; Mühlen et al. 2013; Ndung'u et al. 2014). However, no studies have been conducted on the genetic diversity of cassava with molecular markers in the Cuiabá Lowland region in the state of Mato Grosso, Brazil. This area is within the region considered as the center of origin and domestication as well as a center of diversity of the species (Isendahl 2011; Olsen 2004).

These studies are urgently needed to clarify the agrobiodiversity maintained in this region due to considerable socioeconomic changes and expansion of large-scale agribusiness, mainly in the west-central states. This ongoing expansion forces traditional farmers to migrate, mainly to urban centers, since there are few remaining open agricultural frontiers. In our study area, the Cuiabá Lowland, agribusiness pressure is still small but growing, with more area being cultivated with soybean and sugarcane (Marchetti et al. 2013).

A previous ethnobotanical study was conducted in this area, in the municipality of Santo Antônio do Leverger, with the aim of characterizing the local varieties of cassava and the traditional knowledge and management associated (Amorozo 2000). A recent study (Marchetti et al. 2013) has reported on the changes in the assortment of manioc varieties cultivated by these farmers, comparing the situation in 2011 with the situation found two decades ago, in 1992. Our study represents a continuity of the studies presented by Amorozo (2000) and Marchetti et al. (2013), going back to the same area, and adding two other municipalities, Cáceres and Porto Estrela, situated within the Cuiabá Lowland in the state of Mato Grosso. In these areas, we find farmers established in traditional communities, urban households, and rural settlements, recreating up to a certain point their culture brought from their original areas. And this poses a question: in these situations is agrobiodiversity still maintained? What is the impact, positive or negative, on agrobiodiversity? Therefore, this study aimed at characterizing the genetic diversity and structure of local varieties of $M$. esculenta subsp. esculenta using microsatellite markers in these different life situations at the Baixada Cuiabana, in order to answer these questions.

\section{Materials and Methods}

\section{Plant Materials and Study Area}

We analyzed 211 cassava accessions grown by small farmers in Mato Grosso, collected in 40 households of 10 traditional communities, urban households and rural settlements, in the municipalities of Cáceres, Santo Antônio do Leverger, and 
Porto Estrela (Table 1, Fig. 1). Young cassava leaves were collected directly from the farmers' fields and placed in microtubes containing CTAB (Cetyltrimethylammonium bromide) gels.

The communities were chosen based on previous visits to the region in which the capability of managing and maintaining agrobiodiversity and interest in participating in the survey were analyzed, prioritizing those who had participated in previous ethnobotanical studies. In the municipalities of Santo Antônio do Leverger and Porto Estrela, all field plots and households were visited and cassava genotypes were collected for genetic analysis of all varieties inventoried in the fields. In the municipality of Cáceres, the choice of collecting areas was initially directed at farmers producing cassava for family consumption; then the collection was expanded to farmers who produced in small production chains where the sale of the production was destined for small fairs and school lunch programs from the county.

Although we sampled cassava accessions in communities, urban households, and rural settlements, as described above, we will mention these population groups as communities in the text most of the time, to make it easier for comparison among them. The study area, therefore, includes proper traditional rural populations, urban households on the outskirts of cities, and rural settlements within the Cuiabá Lowland and rural populations in transition, which have been losing their traditional features due to intense interaction with urban centers, no continuity of local activities by younger generations, increasing dependence on market, etc.
The climate in the study area is predominantly tropical, with two well-defined seasons: a rainy season from October to March, and a well-marked dry season from April to September. The mean annual precipitation is about $1,380 \mathrm{~mm}$, and the mean annual temperature is about $25^{\circ} \mathrm{C}$.

\section{DNA EXTRACTION AND SSR AMPLIFICATION}

Young leaves were inserted into $1.5 \mathrm{~mL}$ microtubes containing $\mathrm{CTAB}$ gels, at a proportion of $15 \% \mathrm{CTAB}$ and $6 \mathrm{M} \mathrm{NaCl}$ (Bhattacharjee et al. 2009). The leaves, transported under room temperature to the laboratory in this gel, were then kept in the refrigerator for a minimum of seven days. Genomic DNA extraction from fresh leaves was conducted using a modified Doyle and Doyle (1987) protocol. To calculate the amount of extracted DNA, horizontal electrophoresis in 1\% agarose gels was performed using the SYBr GREEN (Life Technologies, California, USA) staining procedure. The bands were visualized with a digital image sensor, on a photo documenter containing an UV transilluminator Model Z - 21.

Amplification reactions were standardized in a final volume of $10 \mathrm{uL}$ containing: $10 \mathrm{ng}$ of genomic DNA, Taq-polymerase (0.5 U); Buffer (10X); $\mathrm{MgCl}_{2}(1.5 \mathrm{mM})$; forward and reverse primers (0.12 pmol each); dNTP (0.25 mM); and milli-Q $\mathrm{H}_{2} \mathrm{O}$. Fourteen primers predetermined by Chavarriaga-Aguirre et al. (1998) and Mba et al. (2001) were used in this study (Table 2). PCR reactions were carried out under the following conditions: $94^{\circ} \mathrm{C}$ for $1 \mathrm{~min}$, followed by 33 cycles at

TABle 1. Number of CASSAVA (MANIHOT ESCULENTA) ACCESSIONS ANALYZED BY MUNICIPALITY AND COMMUNITY AND THEIR RESPECTIVE GEOGRAPHIC COORDINATES.

\begin{tabular}{|c|c|c|c|c|c|c|}
\hline \multirow{2}{*}{$\begin{array}{l}\text { Municipality } \\
\text { Cáceres }\end{array}$} & \multirow{2}{*}{$\frac{\text { No. }}{1}$} & \multirow{2}{*}{$\frac{\text { Community }}{\text { Santo Antônio } 1}$} & \multirow{2}{*}{$\frac{\text { No. of accessions }}{13}$} & \multirow{2}{*}{$\begin{array}{l}\begin{array}{c}\text { Farm } \\
\text { System* }\end{array} \\
\text { UH }\end{array}$} & \multicolumn{2}{|c|}{$\begin{array}{l}\text { Geographic coordinates } \\
\text { Latitude Longitude }\end{array}$} \\
\hline & & & & & $16^{\circ} 06^{\prime} 36.9^{\prime \prime S}$ & $57^{\circ} 40^{\prime} 27.6^{\prime \prime W}$ \\
\hline Cáceres & 2 & Santo Antônio 2 & 7 & UH & $16^{\circ} 06^{\prime} 19.5^{\prime \prime S}$ & $57^{\circ} 40^{\prime} 42.5^{\prime \prime W}$ \\
\hline Cáceres & 3 & Cidade nova & 8 & UH & $16^{\circ} 05^{\prime} 51.5^{\prime \prime S}$ & $57^{\circ} 40^{\prime} 57.7^{\prime \prime W}$ \\
\hline Cáceres & 4 & Junco & 6 & $\mathrm{UH}$ & $16^{\circ} 06^{\prime} 1.40^{\prime \prime S}$ & $57^{\circ} 41^{\prime} 04.0^{\prime \prime W}$ \\
\hline Cáceres & 5 & Jardim do trevo & 6 & $\mathrm{UH}$ & $16^{\circ} 05^{\prime} 43.0^{\prime \prime} \mathrm{S}$ & $57^{\circ} 40^{\prime} 29.3^{\prime \prime W}$ \\
\hline Cáceres & 6 & Boa esperança & 10 & TA & $16^{\circ} 04^{\prime} 41.4^{\prime \prime S}$ & $57^{\circ} 38^{\prime} 57.9^{\prime \prime W}$ \\
\hline Santo Antônio de Leverger & 7 & Varginha & 37 & TA & $15^{\circ} 48^{\prime} 42.5^{\prime \prime S}$ & $56^{\circ} 06^{\prime} 32.5^{\prime \prime W}$ \\
\hline Santo Antônio de Leverger & 8 & Barreirinho & 40 & TA & $15^{\circ} 49^{\prime} 04.3^{\prime \prime S}$ & $56^{\circ} 01^{\prime} 39.3^{\prime \prime W}$ \\
\hline Porto estrela & 9 & Luzia & 39 & TA & $15^{\circ} 33^{\prime} 43.4^{\prime \prime S}$ & $57^{\circ} 19^{\prime} 58.2^{\prime \prime W}$ \\
\hline Porto estrela & 10 & Banco da terra & 45 & RS & $15^{\circ} 35^{\prime} 24.7^{\prime \prime S}$ & $57^{\circ} 18^{\prime} 38.0^{\prime \prime W}$ \\
\hline
\end{tabular}

${ }^{*} \mathrm{UH}=$ Urban households; RS = Rural settlement; TA = Traditional agriculture farming system. 


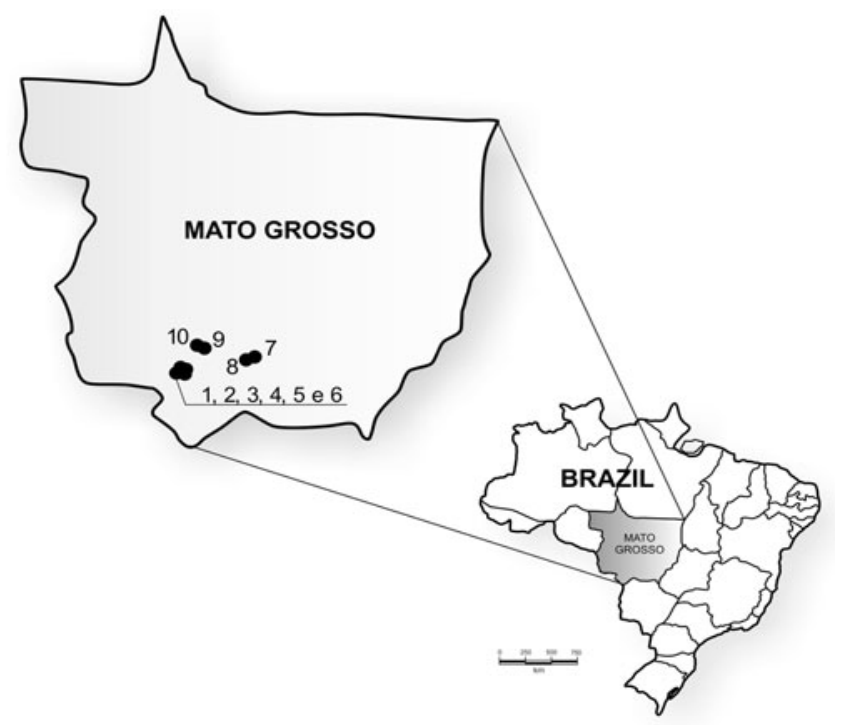

Fig. 1. Brazil map with the location of the study sites in the municipalities of Cáceres $(1,2,3,4,5,6)$, Santo Antônio do Leverger $(7,8)$ and Porto Estrela $(9,10)$ in Mato Grosso state, Brazil.

$94^{\circ} \mathrm{C}$ for $30 \mathrm{~s}, 55^{\circ} \mathrm{C}$ or $50^{\circ} \mathrm{C}$ according to the specific annealing temperatures for each primer for $45 \mathrm{~s}$, and $72^{\circ} \mathrm{C}$ for $1 \mathrm{~min}$, ending with a final extension phase at $72^{\circ} \mathrm{C}$ for $5 \mathrm{~min}$. Amplification products were separated on $6 \%$ polyacrylamide denaturing gels. TBE $1 \mathrm{X}$ buffer was used for electrophoresis, conducted at $1880 \mathrm{~V}$ for approximately 4.5 hours. To visualize the amplified bands, Creste et al. (2001) silver nitrate staining protocol was used.

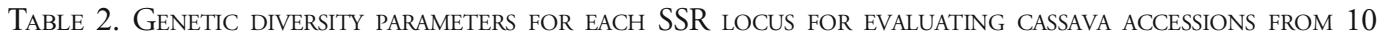
COMMUNITIES OF THE CUIABÁ LOWLAND ${ }^{1}$

\begin{tabular}{|c|c|c|c|c|c|c|c|c|c|}
\hline Primer Name & Observed size $(b p)$ & $\mathrm{N}$ & $A$ & $H_{o}$ & $H_{e}$ & $H_{s}$ & $H_{t}$ & $D_{s t^{\prime}}$ & $G_{s t^{\prime}}$ \\
\hline SSRY8* & $282-298$ & 191 & 3 & 0.64 & 0.87 & 0.638 & 0.642 & 0.005 & 0.008 \\
\hline GA12** & $138-150$ & 207 & 3 & 0.57 & 0.73 & 0.484 & 0.495 & 0.012 & 0.025 \\
\hline SSRY21* & $160-192$ & 196 & 3 & 0.62 & 0.53 & 0.525 & 0.551 & 0.029 & 0.052 \\
\hline SSRY27* & $265-280$ & 191 & 4 & 0.55 & 0.38 & 0.729 & 0.745 & 0.018 & 0.024 \\
\hline SSRY28* & $100-120$ & 199 & 3 & 0.35 & 0.46 & 0.688 & 0.731 & 0.048 & 0.065 \\
\hline SSRY35* & $277-285$ & 184 & 3 & 0.57 & 0.45 & 0.517 & 0.656 & 0.155 & 0.230 \\
\hline SSRY40* & $220-238$ & 190 & 4 & 0.62 & 0.52 & 0.496 & 0.585 & 0.098 & 0.165 \\
\hline SSRY43* & $236-254$ & 173 & 4 & 0.66 & 0.43 & 0.392 & 0.430 & 0.042 & 0.097 \\
\hline SSRY47* & $235-256$ & 182 & 4 & 0.62 & 0.48 & 0.681 & 0.669 & -0.014 & -0.020 \\
\hline SSRY126* & $180-217$ & 199 & 4 & 0.70 & 0.61 & 0.399 & 0.407 & 0.009 & 0.022 \\
\hline SSRY141* & $233-241$ & 187 & 4 & 0.72 & 0.65 & 0.565 & 0.637 & 0.080 & 0.125 \\
\hline SSRY161* & $183-212$ & 192 & 3 & 0.65 & 0.82 & 0.642 & 0.643 & 0.001 & 0.001 \\
\hline SSRY183* & $205-220$ & 200 & 3 & 0.63 & 0.62 & 0.506 & 0.537 & 0.035 & 0.065 \\
\hline SSRY235* & $218-250$ & 194 & 3 & 0.52 & 0.61 & 0.551 & 0.579 & 0.031 & 0.053 \\
\hline Average & - & 191.8 & 3.64 & 0.60 & 0.58 & 0.558 & 0.593 & 0.039 & 0.065 \\
\hline
\end{tabular}

${ }^{1} \mathrm{bp}=$ observed size in base pairs, $\mathrm{N}=$ number of genotypes analyzed, $A=$ number of alleles, $H_{o}=$ observed heterozygosity, $H_{e}=$ expected heterozygosity, $H_{s}=$ genetic diversity within communities, $H_{t}=$ total genetic diversity, $D_{s t^{\prime}}=$ genetic diversity among communities, and $G_{s t^{\prime}}=$ proportion of genetic diversity among communities.

${ }^{*}$ Mba et al. (2001), ${ }^{* *}$ Chavarriaga-Aguirre et al. (1998). 


\section{Genetic Diversity Analysis}

For the statistical analysis, we estimated the genetic diversity for each population (considering each community, urban households, and rural settlement as the population in this study, which included gardens or yards containing at least three to four cassava local varieties). For each locus and for each community, the following indices were estimated: allele frequencies, number of alleles per locus, observed heterozygosity, expected heterozygosity (Nei 1978) or gene diversity, and fixation index. The genetic structure of populations was assessed using Nei's (1973) genetic diversity parameters, such as the total genetic diversity $\left(H_{T}\right)$, genetic diversity within communities $\left(H_{S}\right)$, genetic diversity among communities $\left(D_{S T}\right)$, and the proportion of genetic diversity among communities $\left(G_{S T}\right)$. For these analyses, the GENALEX 6.0 (Peakall and Smouse 2006), FSTAT (FSTAT, version 2.9.3), and GDA (Genetic Data Analysis, Version 1.0) softwares were used.

An analysis of molecular variance (AMOVA) was performed using the program Arlequin v.3.5 (Excoffier and Lischer 2010) in order to assess the level of variability among three levels, that is, among municipalities, among communities within municipalities, and within communities. AMOVA was also used for the analysis of intra- and intervarietal variability, namely, among and within local varieties. For this analysis, the following approach was used: all genotypes with the same popular name within a community were grouped, considering a local variety as a set of accessions with the same name as given by the farmers, following the methodology used by Kizito et al. (2007). A third AMOVA analysis was performed to compare the level of diversity among and within farming systems, namely, traditional and non-traditional farming systems.

To visualize the distribution of the genetic differentiation, Nei's (1972) genetic distances were estimated using the TFPGA software (Tools for Population Genetic Analyses), and dendrograms were constructed using the Unweighted Neighbor-Joining method and DARwin5 software (Perrier et al. 2003). A Bayesian analysis was also performed with the program STRUCTURE 2.3 (Pritchard et al. 2000) to define groups of genetically related individuals. For this analysis, 20 independent simulations for each $\mathrm{K}$ value ( $\mathrm{K}=1$ to 10$)$ were performed. In each simulation, 500,000 Monte Carlo simulations of Markov chains
(MCMC) were made with an initial discard (burn-in) of 200,000. The most likely cluster number was estimated by the Evanno et al. (2005) method. The Biodiversity software DIVA GIS (Hijmans et al. 2001) was also used to obtain the geographical distribution of diversity in these municipalities and also to estimate the allelic richness in the study areas.

\section{Results and Discussion}

\section{Conservation of Genetic Diversity}

A total of 48 alleles, with an average of 4 alleles per locus, was obtained for the 211 genotypes analyzed with 14 microsatellite loci (Table 2). Six private alleles were found in the three studied municipalities, mostly concentrated in Santo Antônio do Leverger, followed by Cáceres and Porto Estrela. The number of alleles per locus found in this study is similar to that found in other studies, such as those reported by Siqueira et al. (2010) assessing cassava originating in Mato Grosso do Sul with microsatellite markers, with the number of alleles per locus ranging from 2 to 5 , and 4 on average. The number of alleles per locus found by Chepkoech et al. (2015), among 10 cassava genotypes (cassava mutants, hybrids, and landraces from Kenya), detected with 11 SSR primers ranged from 2 to 4 with an average of 2 alleles per locus. Ndung'u et al. (2014) reported a higher number of alleles per locus, varying from 4 to 8 , with 6 on average, when looking at the genetic constitution of 69 cassava accessions from different regions in Kenya using seven SSR primers. The higher number of alleles per locus may be due to a wider sample of accessions, from the national ex situ gene banks at Kakamega, Katumani, and Kiboko, including a few samples from advanced IITA lines and CIAT to act as checks. A much higher number of alleles per locus (10 on average) was obtained by Mühlen et al. (2013) using nine SSR loci, when assessing 494 cassava varieties from different regions in Brazil. The higher number of alleles per locus found in Mühlen et al. (2013), however, may be due to a higher and wider sample of cassava varieties, originated from different regions in Brazil.

In our study, the highest proportion of private alleles was found in Santo Antônio do Leverger, on loci SSRY21 (one allele with a frequency of 0.100) and SSRY161 (two alleles with frequencies of 0.021 and 0.007 , respectively), followed by Cáceres 
municipality, also for locus SSRY161 (two alleles with a frequency of 0.018 each), and Porto Estrela, for locus SSRY28 (one allele with a frequency of 0.011). Private alleles, which are those found only in a single population among a broader collection of populations, are important because they can serve as specific markers of a given genotype and help to accentuate the genetic differentiation among populations (Szpiech and Rosenberg 2011). Also, they are considered to be important and informative when determining the priority areas for in situ conservation.

We also found an average observed heterozygosity $\left(H_{O}\right)$ of 0.60 and expected heterozygosity $\left(H_{E}\right)$ of 0.58 for the 14 loci, results that do not differ greatly (Table 2), representing high levels of genetic diversity. High levels of heterozygosity were observed in the three municipalities, with Luzia community in Porto Estrela showing the highest rate $\left(H_{O}=0.725\right)$, followed by Banco da Terra in the same municipality $\left(H_{O}=0.667\right)$ (Table 3$)$. These two communities also showed higher levels of $H_{E}$, as well as the community of Santo Antônio 2, in Cáceres. Similar values were obtained by different researchers who analyzed the genetic diversity in cassava, such as Peroni et al. (2007) evaluating 169 local cassava varieties originating in the Atlantic Forest in São Paulo and Amazon, using nine SSR loci $\left(H_{O}=0.67\right)$, and Mühlen et al. (2013) assessing 494 cassava varieties from different regions in Brazil with nine SSR loci $\left(H_{O}=0.595\right)$. Elias et al. (2004) evaluated local varieties from five locations in South America, in a study with eight loci, obtaining an average of $H_{O}=0.51$.
Regarding the fixation index $(f)$, all communities showed values close to zero, which is common in cross-pollinated plants, and some also showed negative values, which indicates high levels of heterozygosity (Table 3), typical of clonally propagated plants (McKey et al. 2010). Therefore, our results reflect high levels of heterozygosity and low levels of inbreeding, favorable for the increase of diversity and genetic conservation. Similar results were obtained by Alves-Pereira et al. (2011), who evaluated local varieties of manioc cultivated by traditional farmers along the Madeira River in central Amazonia.

When analyzing the different agricultural systems, that is, traditional agriculture systems, urban households, or newly formed rural settlements, we noticed no difference in the level of genetic diversity among them, which is reflected in the observed heterozygosity index. For example, in the urban households in Cáceres municipality $H_{O}$ ranged from 0.535 to 0.613 and the Banco da Terra settlement of Porto Estrela presented a $H_{O}$ of 0.667 . Whereas, in the fields of traditional communities the $H_{O}$ indices ranged from 0.438 to 0.725 (Table 3). Therefore, the levels of genetic diversity in this study were high in all communities under study, whether it be traditional farmers' fields or fields of rural settlements, or located in urban and peri-urban areas, which is an indication that these non-traditional areas of study are also important for the conservation of genetic resources. Despite the changes, including migration and urbanization, agrobiodiversity is being maintained. But this can be a state of transition, and as the changes deepen,

TABLE 3. DiVERSITY INDICES ASSESSED IN CASSAVA, FOR EACH COMMUNITY UNDER STUDY ${ }^{1}$

\begin{tabular}{|c|c|c|c|c|c|c|c|}
\hline \multirow[b]{2}{*}{ Municipality } & \multirow[b]{2}{*}{ Community } & \multicolumn{3}{|l|}{ Farm } & \multirow[b]{2}{*}{$H_{o}$} & \multirow[b]{2}{*}{$H_{e}$} & \multirow[b]{2}{*}{$f$} \\
\hline & & System $^{2}$ & $A$ & $N$ & & & \\
\hline Cáceres & Santo Antônio 1 & $\mathrm{UH}$ & 3.214 & 8.286 & 0.535 & 0.574 & 0.074 \\
\hline Cáceres & Santo Antônio 2 & $\mathrm{UH}$ & 3.143 & 3.929 & 0.577 & 0.591 & 0.030 \\
\hline Cáceres & Cidade Nova & $\mathrm{UH}$ & 2.214 & 2.929 & 0.571 & 0.391 & -0.474 \\
\hline Cáceres & Junco & $\mathrm{UH}$ & 2.571 & 4.000 & 0.607 & 0.533 & -0.126 \\
\hline Cáceres & Jardim do Trevo & $\mathrm{UH}$ & 2.571 & 3.643 & 0.613 & 0.468 & -0.300 \\
\hline Cáceres & Boa Esperança & TA & 2.500 & 6.500 & 0.620 & 0.475 & -0.280 \\
\hline Santo Antônio de Leverger & Varginha & TA & 3.357 & 38.073 & 0.438 & 0.465 & 0.086 \\
\hline Santo Antônio de Leverger & Barreirinho & TA & 3.500 & 37.571 & 0.515 & 0.574 & 0.081 \\
\hline Porto estrela & Luzia & TA & 3.357 & 41.714 & 0.725 & 0.583 & -0.243 \\
\hline Porto estrela & Banco da Terra & RS & 3.429 & 45.429 & 0.667 & 0.599 & -0.127 \\
\hline Average & & & 2.860 & 19.207 & 0.587 & 0.525 & -0.115 \\
\hline
\end{tabular}

\footnotetext{
${ }^{1}$ Including farming system, the average number of analyzed genotypes $(N)$, mean number of alleles per locus $(A)$, mean observed heterozygosity $\left(H_{O}\right)$, mean expected heterozygosity $\left(H_{e}\right)$ and fixation index $(f)$

${ }^{2} \mathrm{UH}=$ Urban households; RS = Rural settlement; TA = Traditional agriculture farming system.
} 
the tendency will be a greater loss of agrobiodiversity, linked to a lower transmission/ assimilation of traditional knowledge, and reduction of areas for cultivation (Marchetti et al. 2013). For instance, in Cáceres, cassava cultivation is carried out mostly $(75 \%)$ by the elderly and its main purpose is for household consumption followed by the sale of surplus production. Among these farmers, three are established in rural areas, and two have kept their farming practices and appropriate processing of cassava with their family for at least 60 years. As for the farmers investigated in peri-urban areas, on the outskirts of Cáceres, these families have moved from rural to urban environments and maintain their crops and processing of cassava, even in smaller areas, where much of their knowledge regarding cassava is preserved. Although these periurban areas allow the maintenance of their practices even in confined spaces, they are subject to two main risks: the lack of replacement of the young labor force and the legalization of land on the outskirts of the city associated with real estate expansion of popular housing units.

It is worthwhile to highlight that the traditional farming practices of the studied communities often contribute not only to the management but also to the expansion of diversity. Besides being vegetatively propagated by farmers, cassava still carries out sexual reproduction, which implies an important role in the evolutionary dynamics of this crop (Martins and Oliveira 2009; McKey et al. 2010; Peña-Venegas et al. 2014). These spontaneous crossings that occur in farmers' fields generate seeds that might become part of the seed bank in the soil, allowing the germination of genotypes generated from crosses among varieties, and some of these seedlings are selected, according to their attractive qualities, to be incorporated in the fields of traditional farmers (Pujol et al. 2007). In our study, we found that farmers still keep plants originating from seeds that elevate the level of genetic diversity. An example of plants grown from seed is the "Joaozinho" local variety that grew spontaneously in a farmer's field of Santo Antônio do Leverger, spreading throughout the community and, after 10 years, was the most planted variety (Amorozo 2000).

In the municipality of Porto Estrela, we studied two communities that were established in similar environments but with quite different historical background. Luzia is a traditional community that, according to its older residents, originated in 1918 by the Sesmarias Land Policy: "Sesmaria Bernardo Dias." The rural settlement Banco da Terra has a much more recent origin, being established in 2001 through the Banco da Terra Program. This program allocates landless people from different parts of the country in individual plots that they cultivate. The high diversity found in this municipality can be attributed to the traditional management practices of Luzia community where the traditional slash and burn agriculture system and community households can still be found, as well as an exchange network of genetic material and their knowledge. This network plays an important role, especially in Banco da Terra, due to the intense bond of its residents with the urban centers of the region, since usually part of the family remains in town to study or work (Oler 2012).

The results of this study show that rural settlements may also play an important role in maintaining biodiversity, especially when practicing subsistence agriculture. The proximity to traditional communities may also contribute to maintain biodiversity. The search for increasing diversity is a common practice among farmers for a better adaptation to changes that may occur-environmental, socioeconomic, etc. (Kizito et al. 2007).

\section{Genetic Structure}

High total genetic diversity was found for the cassava genotypes under study $\left(H_{T}=\right.$ 0.593). This diversity was concentrated within communities $\left(H_{S}=0.558\right)$, while the lowest values were observed among communities $\left(D_{S T}=0.039\right)$ and for the proportion of the observed variation among communities $\left(G_{S T}=0.065\right)$ (Table 2$)$. The analysis of molecular variance (AMOVA) confirmed these results, showing that most of genetic variation is concentrated within communities (92\%), whereas $43 \%$ of genetic differentiation is among communities and only $4 \%$ among municipalities.

This result occurs because traditional farmers are constantly exchanging local varieties, which leads to a high gene flow among communities and even among municipalities, with the highest concentration of genetic diversity within communities $(92 \%)$. Our data coincide with those obtained in Alves-Pereira et al. (2011) with $87 \%$ of genetic variation found within groups of varieties (sweet and bitter) and other studies reported by Kizito et al. (2007)), Mezette et al. (2013), and Siqueira et al. (2010). Yong-Bi et al. (2014), comparing the genetic diversity of 266 cassava clones 
collected from 80 farms in eight provinces with 16 cassava landraces and varieties released from Thailand, also found most variation to be concentrated within groups (farm clones versus varieties, with $99 \%$ ), within farms $(80 \%)$, within districts $(87 \%)$, and within provinces $(88 \%)$.

In the genetic tree obtained from the cluster analysis (Fig. 2), a tendency for the formation of two groups was observed. The first group was formed mostly by accessions from Santo Antônio do Leverger (S), and the second included mostly accessions from the municipalities of Cáceres (C) and Porto Estrela (P), with some exceptions. Bayesian analysis conducted with Structure software confirmed these results, and suggested the separation of the accessions into two groups (Fig. 3). Within these groups there are some exceptions, which must be due to gene flow, which exists among municipalities. But despite this gene flow, there is a moderate genetic differentiation between these two groups. This result may be related to the fact that Cáceres is geographically closest to Porto Estrela $(113 \mathrm{~km})$, which favors the exchange of material between these two municipalities, while

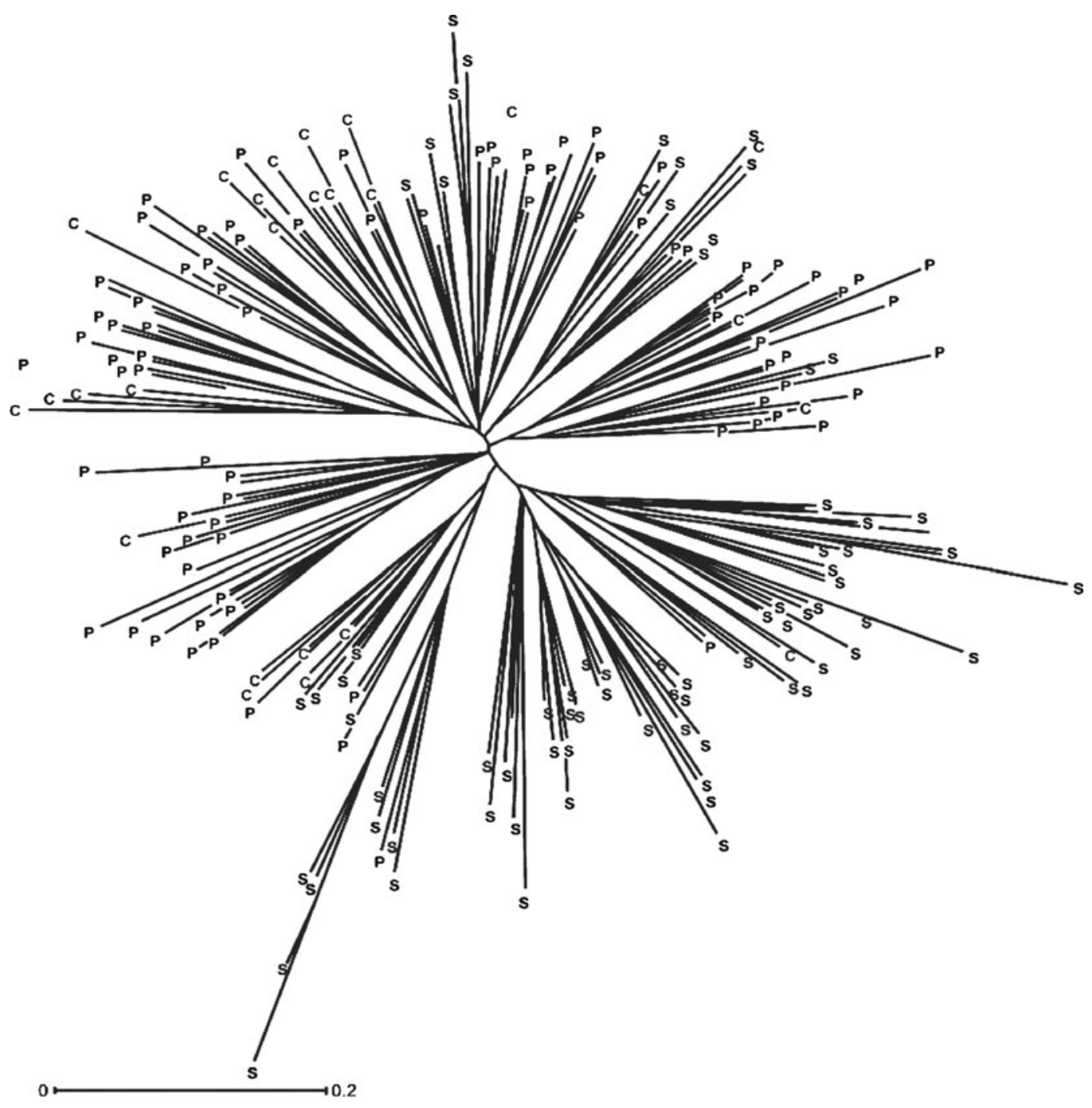

Fig. 2. Genetic tree for 211 accessions of cassava (Manihot esculenta) in the municipalities of Cáceres (C), Santo Antônio do Leverger (S), and Porto Estrela (P). 


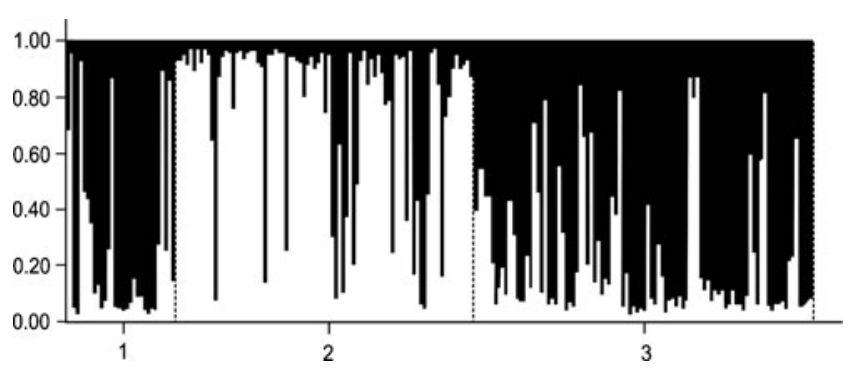

Fig. 3. Bayesian analysis showing the classification of 211 cassava (Manihot esculenta) accessions in two groups $(K=2)$ according to Structure software, where each individual is represented by a vertical line and the lengths indicate the proportions of the inferred genome assigned to each group. Populations 1 and 3 represent accessions from Cáceres and Porto Estrela municipalities, mostly classified into group 1 (black), while population 2 represents Santo Antônio do Leverger municipality, mostly classified into group 2 (white).

Santo Antônio do Leverger is situated $242 \mathrm{~km}$ from Cáceres and $240 \mathrm{~km}$ from Porto Estrela.

In the cluster analysis considering the $10 \mathrm{com}-$ munities, a genetic differentiation was found among communities. These communities are grouped according to the municipality of origin, with few exceptions (Fig. 4), and shows clearly that communities of Santo Antônio do Leverger (Barreirinho and Varginha) form a well-structured group. Moreover, there are some differences regarding cultural aspects related to the selection of local varieties maintained in the three municipalities. Farmers usually divide the cassava varieties in two groups, related to the glycoside-cyanogenic content $(\mathrm{HCN})$ (Mühlen et al. 2013; Peña-Venegas et al. 2014; Peroni et al. 2007): sweet cassava, that corresponds to what is used for household consumption, presenting low cyanogenic potential, and bitter cassava, with high cyanogenic potential that can be toxic and require special processing to facilitate its use, such as the processing of the roots into flour. In Santo Antônio do Leverger, farmers cultivate both sweet (about 90\% of the local varieties) and bitter cassava (10\% of the local varieties) (Marchetti et al. 2013). In the other two municipalities, farmers only cultivate sweet cassava. In Porto Estrela municipality, the families in the Banco da Terra settlement currently do not produce flour, not even for their own consumption. The flour consumed is acquired in urban centers. In the Luzia community, there are reports of flour production, but not as the most important source of income for the community. This production was practically wiped out and today some families make flour for personal use and donation to other family members. Fresh cassava consumption is the most common in the area (Oler 2012). It is possible that these facts have influenced the genetic separation of these two groups in the genetic tree.

In the cluster analysis, considering the community level, it is clearly evident that the communities of Santo Antônio do Leverger (Barreirinho and Varginha) formed a separate group. In this analysis we also observed that cassava from Santo Antônio 2, in Cáceres, is genetically closer to local varieties from the Banco da Terra settlement, in Porto Estrela. This result is probably due to the fact that a farmer from Santo Antônio 2 has family and political relations in the municipality of Porto Estrela. It is worth observing that farmers in Cáceres live in the outskirts of town and are from different origins. Usually originated from different rural communities, these residents grow plants in their home gardens and are important elements in the gene flow of local varieties and knowledge, and such a situation is evident in the current study. Another relevant issue is the importance of urban agriculture in maintaining agrobiodiversity, which was also evident in this work.

In Santo Antônio do Leverger, besides the fact that the two communities (Barreirinho and Varginha) are well differentiated from the other municipalities, we also observed genetic differences between them, most likely due to soil differences, considering that Varginha has a rocky soil type and is located at a distance of about 1 kilometer from the river. On the other hand, Barreirinho has a clay soil where small waterlogged areas are observed during the rainy season (Amorozo 2000). Farmers grow local varieties adapted to these aspects of soil characteristics in each community. For example, farmers in Varginha grow the local variety "Vermelha-deJoaozinho" because, according to them, it develops better in rocky soils, while farmers in Barreirinho 


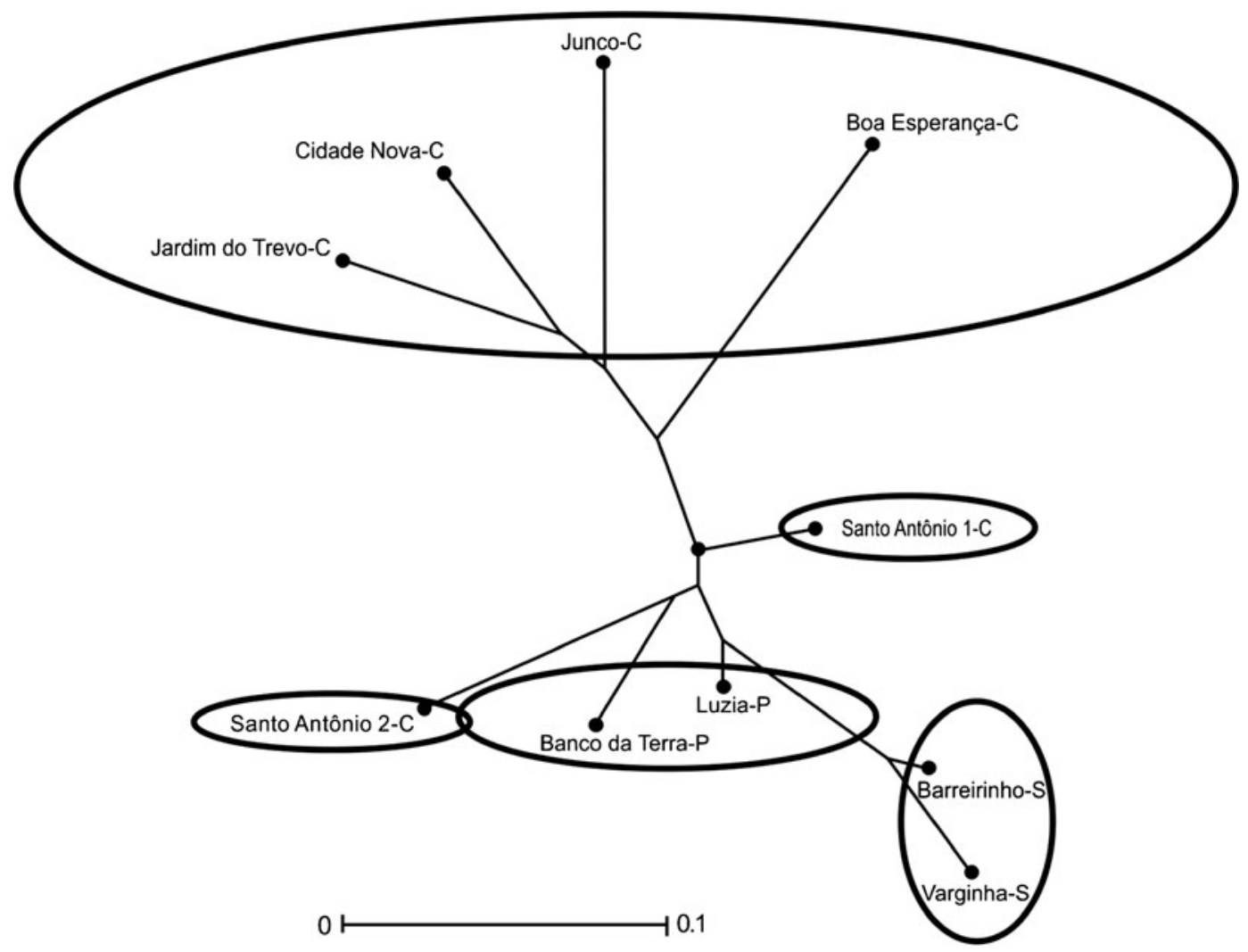

Fig. 4. Genetic tree for the communities under study: Cáceres (C) (Santo Antônio 1, Santo Antônio 2, Cidade Nova, Junco, Jardim do Trevo and Boa Esperança), Santo Antônio do Leverger (S) (Varginha and Barreirinho) and Porto Estrela (P) (Luzia and Banco da terra).

cultivate the local variety "Rama-dura," which is well adapted to clay soils. Such factors may be leading to the genetic differentiation observed between the two communities of Santo Antônio do Leverger.

\section{Conservation of Local Varieties IN THE FIELDS}

Among 211 genotypes sampled in the three municipalities (Cáceres, Porto Estrela, and Santo Antônio do Leverger), 83 cassava local varieties were registered, considering a local variety a group of accessions bearing the same name as attributed by the farmers. Cáceres showed less local varieties compared to the other municipalities, with a total of 23. Porto Estrela presented 37 while Santo Antônio do Leverger had 40 local varieties. Most of these varieties were found to be unique to a municipality and not found in other municipalities. Cáceres showed
14 unique local varieties (61\%), whereas Porto Estrela presented 31 (84\%), while Santo Antônio do Leverger presented 33 (83\%). The latter two municipalities had more unique local varieties than Cáceres.

The frequency of each local variety was recorded throughout the study area and the most frequent were "Cacau" (17\%) and "Branca" (16\%), followed by "Liberata" and "Amarela" with $9 \%$ each (Fig. 5). When we analyzed them by municipality, Cáceres showed a larger amount of "Cacau" (36\%) followed by "Três meses" (19\%). In Porto Estrela, the most frequent was "Cacau" (17\%) followed by "Amarela" (14\%). Finally, Santo Antônio do Leverger showed a higher frequency of "Olhuda" (11\%) followed by "Mata-rato" (9\%).

One of the questions we had was if there is genetic variability among the accessions of the same local variety, according to the farmers' classification. When we analyzed the differentiation among and 


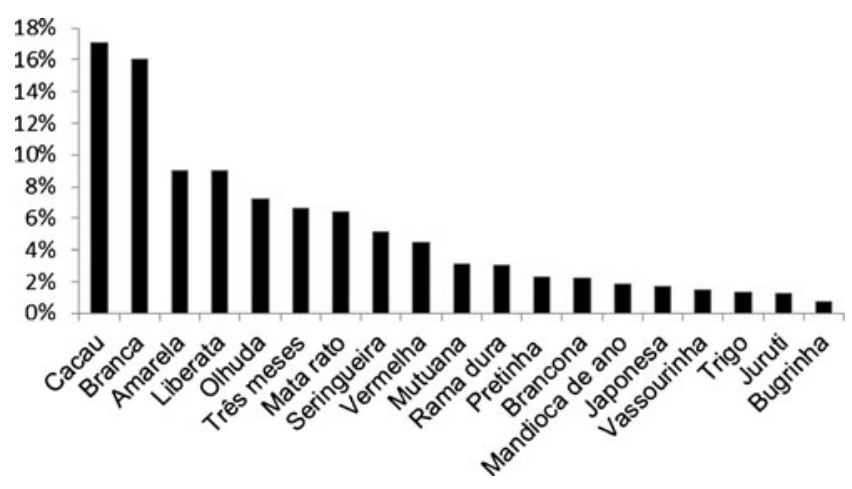

Fig. 5. Percentage of local varieties of cassava (Manihot esculenta) observed in the municipalities of Cáceres, Porto Estrela, and Santo Antônio do Leverger in Cuiabá Lowland, Mato Grosso.

within local varieties in each municipality, we found no clustering of the same local varieties, observing great differentiation among and within local varieties within each municipality. The genetic trees per municipality (data not shown) revealed that some local varieties, bearing the same popular name, from the same community were distant from each other, which means that they were genetically different. However, during the collections on the field we found that the name given by the farmers for a particular variety was phenotypically very coherent, which means that, for example, all varieties of "Rama-dura" or "Mata-rato" showed similar morphological characteristics from different farmers in the same community. But what the molecular markers are showing is that although they may be phenotypically very similar, they may still be genetically different (Basheer-Salimia et al. 2012; Sameh et al. 2014). The AMOVA analysis was another quantitative tool to confirm the existing genetic differentiation among and within local varieties, showing that $97 \%$ of the genetic differentiation lies within local varieties, and only $3 \%$ among the local varieties.

Local varieties in this study originated from different places and are products of migration, since traditional farmers are used to exchanging materials as well as keeping several local varieties on the same field. They grow local varieties of cassava, either sweet or bitter, for food security, due to the threats of pests and diseases, ensuring production, considering that some varieties are more resistant to biotic and abiotic factors then others (Bellon 1996). We observed that in the three municipalities, the cultivation of "Cacau," "Branca," "Liberata," and "Amarela" local varieties are preferred due to the good characteristics of adaptability, yield and cooking quality, which was also observed in the studies of Amorozo (2000) and Marchetti et al. (2013). However, this study showed that farmers in Cáceres, Santo Antônio do Leverger, and Porto Estrela maintain a great diversity of cassava in their fields, where farmers are able to morphologically differentiate these varieties.

Apart from knowing the genetic diversity, it is useful to define priority areas for conservation. For this goal, a priority area for the population conservation is that which retains the most common local alleles produced in high frequency in a limited area, possibly indicating the presence of genotypes adapted to specific environments (Zonneveld et al. 2012). Another important feature to be taken into account to define a reserve area is one that includes the highest number of different alleles. The municipality of Santo Antônio do Leverger constitutes such an area, due to the presence of high levels of genetic diversity, but also because it concentrated constant frequency of the most common alleles in its populations and the presence of private alleles. For these reasons, this municipality should be considered a priority area for in situ conservation. However, there are socio-environmental issues to be considered in this area, which is facing a diminished labor force due to the out-migration of the younger generation, who are employed in urban centers or engaged in non-agricultural jobs, thus adding to the aging of the rural population and the expansion of large-scale agribusiness (Marchetti et al. 2013). There is a strong need for public policies that pay special attention to local traditional management and processes that maintain agrobiodiversity and that reassure the younger 
generation of a better quality of life without abandoning their way of life and their cultural values.

\section{Conclusions}

High cassava diversity was found in three communities in the Cuiabá Lowland. This area is considered the center of origin and domestication of cassava. A moderate genetic structure led to the separation of the local varieties into two groups, which may reflect differences regarding cultural aspects related to the selection of local varieties maintained in the three municipalities.

We conclude that local varieties, according to the names provided by the farmers, are not homogeneous, showing genetic variation within a variety, although phenotypically the farmers' classification is coherent. Another important discovery is that high levels of genetic diversity exists in traditional farmers' fields, in urban households, and in rural settlements, which means that newly founded rural settlements still maintain traditional farming practices. This is important in terms of conservation of cassava diversity.

Further studies in different areas of Brazil's state of Mato Grosso are now being conducted by our group with microsatellite markers. These should provide data to compare with our results. Also, more up-to-date molecular markers, such as SNPs, obtained through next-generation sequencing, will be important for more accurate estimates of genetic diversity and structure. All of these studies, indeed, are important in order to inform and direct public policies regarding on farm conservation practices of cassava at the Baixada Cuiabana area and also to indicate priority areas for conservation. The work that has been conducted by our research group in these areas has made farmers as well as a new generation of students more aware of the important role of traditional communities in the conservation of cassava varieties.

\section{Acknowledgments}

The authors thank FAPESP for their support in funding the project $n^{\circ} 2008 / 03822-3$, PEC-PG/ $\mathrm{CNPq}$ and $\mathrm{CNPq}$ for the scholarships granted to NFC and EAV; and the farmers for providing the genotypes for this study. This publication contains traditional knowledge associated with Brazilian biodiversity. Pursuant to Provisional Measure no. 2.186-16, from August 23, 2001, the access to this knowledge for the purposes of scientific research, bioprospecting, and technological development is subject to the prior consent of the community that detains the knowledge and permission from the Conselho de Gestão do Patrimônio Genético of the Ministério do Meio Ambiente (CGEN - process no. 02000.002717/2009-68).

\section{Literature Cited}

Alves-Pereira, A., N. Peroni, A. A. Gonçalves, R. Gribel, and R. C. Clement. 2011. Genetic structure of traditional varieties of bitter manioc in three soils in Central Amazonia. Genetica 139(10):1259-1271.

Amorozo, M. C. M. 2000. Management and conservation of Manihot esculenta Crantz germplasm by traditional farmers in Santo Antônio do Leverger, Mato Grosso State, Brazil. Etnoecologica 4(6):69-83.

2008. Maintenance and management of agrobiodiversity is small-scale agriculture. Functional Ecosystems and Communities 2(1):11-20.

Basheer-Salimia, R., A. Murad, and J. Ward. 2012. Assessments of biodiversity based on molecular markers and morphological traits among West-Bank, Palestine fig genotypes ( $F i$ cus carica L.). American Journal of Plant Sciences 3(9):1241-1251.

Bellon, R. M. 1996. The dynamics of crop infraspecific diversity: A conceptual framework at the farmer level. Economic Botany 50(1):26-39.

Bhattacharjee, R., M. Ferguson, M. Gedil, D. Dumet, and I. Ingelbrecht. 2009. Field collection, preservation and large scale DNA extraction procedures for cassava (Manihot esculenta Crantz.). African Journal of Biotechnology 8: 3424-3430.

Chavarriaga-Aguirre, P., M. M. Maya, M. W. Bonierbale, S. Kresovich, M. A. Fregene, J. Tohme, and G. Kochert. 1998. Microsatellites in cassava (Manihot esculenta Crantz): Discovery, inheritance and variability. Theoretical and Applied Genetics 97(3):493-501.

Chepkoech, E., M. Kinyua, O. Kiplagat, E. E. Arunga, and S. Kimno. 2015. Genetic diversity of cassava mutants, hybrids and landraces using simple sequence repeat markers. American Journal of Experimental Agriculture 5(4):287-294.

Creste, S., A. N. Tulmann, and A. Figueira. 2001. Detection of single sequence repeat polymorphisms in denaturing polyacrilamide sequencing 
gels by silver staining. Plant Molecular Biology Reporter 19(4):299-306.

Doyle, J. J. and J. L. Doyle. 1987. A rapid DNA isolation procedure for small quantities of fresh leaf tissue. Phytochemistry Bulletin 19:11-15.

El-Sharkawy, A. M. 2004. Cassava biology and physiology. Plant Molecular Biology 56(4): 481-501.

Elias, M., G. S. Muhlen, D. Mckey, A. C. Roa, and J. Tohme. 2004. Genetic diversity of traditional South American local varieties of cassava (Manihot esculenta Crantz): Analysis using microsatellites. Economic Botany 58(2): 242-256.

Evanno, G., S. Regnaut, and J. Goudet. 2005. Detecting the number of clusters of individuals using the software Structure: A simulation study. Molecular Ecology 14(8):2611-2620.

Excoffier, L. and H. E. L. Lischer. 2010. Arlequin suite ver 3.5: A new series of programs to perform population genetics analyses under Linux and Windows. Molecular Ecology Resources 10(3):564-567.

FAOSTAT. 2013. Food and Agriculture Organization of the United Nations. 2011. http://faostat. fao.org $/$ site $/ 567 /$ DesktopDefault.aspx?PageID= 567 (13 June 2013).

Hijmans, R. J., L. Guarino, M. Cruz, and E. Rojas. 2001. Computer tools for spatial analysis of plant genetic resources data. 1. DIVAGIS. Plant Genetic Resources Newsletter 127: 15-19.

Isendahl, C. 2011. The domestication and early spread of manioc (Manihot esculenta Crantz): A brief synthesis. Latin American Antiquity 22(4): 452-468.

Kizito, B. E., L. Chiwona-Kartlum, T. Egwang, and M. Fregene. 2007. Genetic diversity and variety composition of cassava on small scale farms in Uganda: An interdisciplinary study using genetic markers and farmer interviews. Genetica 130(3):301-318.

Marchetti, F. F., L. R., Jr. Massaro, M. C. Amorozo, and D. Butturi-Gomes. 2013. Maintenance of manioc diversity by traditional farmers in the state of Mato Grosso, Brazil: A 20-year comparison. Economic Botany 67(4): 313-323.

Martins, P. S. and G. C. X. Oliveira. 2009. Dinâmica evolutiva em roças de caboclos amazônicos. In: Diversidade biológica e cultural da Amazônia. 2nd edition, eds., I. C. G. Vieira, J. M. C. Silva, D. C. Oren, and M. Â. D'Incao,
373-391. Belém, Brazil: Museu Paraense Emílio Goeldi.

Mba, R. E. C., P. Stephenson, K. Edwards, S. Melzer, J. Nkumbira, U. Gullberg, K. Apek, M. Gale, J. Tohme, and M. Fregene. 2001. Simple sequence repeats (SSR) markers survey of the cassava (Manihot esculenta Crantz) genome: Towards an SSR-based molecular genetic map. Theoretical and Applied Genetics 102(1): 21-31.

McKey, D., M. Elias, B. Pujol, and A. Duputie. 2010. The evolutionary ecology of clonally propagated domesticated plants. New Phytologist 186(2):318-332.

Mezette, T. F., C. G. Blumer, and E. A. Veasey. 2013. Morphological and molecular diversity among cassava genotypes. Pesquisa Agropecuária Brasileira 48(5):510-518.

Mühlen, G., A. Alves-Pereira, C. R. Clement, and T. L. Valle. 2013. Genetic diversity and differentiation of Brazilian bitter and sweet manioc varieties (Manihot esculenta Crantz, Euphorbiaceae) based on SSR molecular markers. Tipití: Journal of the Society for the Anthropology of Lowland South America 11(2):66-73.

Ndung'u, J. N., F. N. Wachira, M. G. Kinyua, D. K. Lelgut, P. Njau, H. Okwaro, and H. Obiero. 2014. Genetic diversity study of Kenyan cassava germplasm using simple sequence repeats. African Journal of Biotechnology 13(8):926-935.

Nei, M. 1972. Genetic distance between populations. American Naturalist 106(949):283-292. 1973. Analysis of gene diversity in subdivided populations. Proceedings of the $\mathrm{Na}-$ tional Academy of Sciences 70(12):3321-3323.

1978. Estimation of average heterozygosity and genetic distance from a small number of individuals. Genetics 89(3):583-590.

Oler, J. R. L. 2012. Conservaçáo da agrobiodiversidade por agricultores de pequena escala em Mato Grosso. Dissertation, Ecology Department, São Paulo State University, Brazil, Brasil.

Olsen, M. K. 2004. SNPs, SSRs and inferences on cassava's origin. Plant Molecular Biology 56(4): 517-526.

Peakall, R. and P. E. Smouse. 2006. GENALEX 6: genetic analysis in Excel. Population genetic software for teaching and research. Molecular Ecology Notes 6(1):288-295.

Peña-Venegas, C. P., T. J. Stomph, L. Verschoor, A. B. Lopez-Lavalle, and P. C. Struik. 2014. Differences in manioc diversity among five 
ethnic groups of the Colombian Amazon. Diversity 6:792-826.

Peroni, N., P. Y. Kageyama, and A. Begossi. 2007. Molecular differentiation, diversity, and folk classification of "sweet" and "bitter" cassava (Manihot esculenta) in Caiçara and Caboclo management systems (Brazil). Genetic Resources and Crop Evolution 54(6):1333-1349.

Perrier, X., A. Flori, and F. Bonnot, 2003. Data analysis methods. In: Genetic diversity of cultivated tropical plants, eds., P. Hamon, M. Seguin, X. Perrier, J. C. Glaszmann, 43-76. Montpelier, Vermont: Enfield, Science Publishers.

Pritchard, J. K., M. Stephens, and P. Donnelly. 2000. Inference of population structure using multilocus genotype data. Genetics 155(2): 945-959.

Pujol, B., F. Renoux, M. Elias, L. Rival, and D. Mckey. 2007. The unappreciated ecology of landrace populations: Conservation consequences of soil seed banks in cassava. Biological Conservation 136(4):541-551.

Sameh, M. R., S. D. Olfa, B. Saleh, and F. Ali. 2014. Morphological and molecular characterization of the main olive varieties cultivated in the region of Hbebsa (North West of Tunisia).
International Journal of Agronomy and Agricultural Research 5(2):87-93.

Siqueira, M. V. B. M., T. T. Pinheiro, A. Borges, T. L. Valle, M. Zatarim, and E. A. Veasey. 2010. Microsatellite polymorphisms in cassava local varieties from the Cerrado Biome, Mato Grosso do Sul, Brazil. Biochemical Genetics 48(9-10): 879-895.

Sriroth, K. R., S. Chollakup, K. Choineerant, K. Piyachomkwan, and C. G. Oates. 2000. Processing of cassava wastes for improved biomass utilization. Bioresource Technology 71:63-70.

Szpiech, Z. A. and N. A. Rosenberg. 2011. On the size distribution of private microsatellite alleles. Theoretical Population Biology 80:100-113.

Yong-Bi, F., P. P. Wangsomnuk, and R. Benjawan. 2014. Thai elite cassava genetic diversity was fortuitously conserved through farming with different sets of varieties. Conservation Genetics 15(6):1463-1478.

Zonneveld, M. V., X. Scheldeman, P. Escribano, M. A. Viruel, P. V. Damme, W. Garcia, C. S. Tapia, J. Romero, M. Sigueńas, and J. I. Hormaza. 2012. Mapping genetic diversity of cherimoya (Annona cherimola Mill.): Application of spatial analysis for conservation and use of plant genetic resources. Plos One 7(1):1-14. 